УДК 332.1: 331.55

DOI: $10.15673 /$ fie.v10i4.1138

\author{
Савенко I.I. \\ доктор економічних наук, професор \\ E-mail: kaf-ml@gmail.com \\ Седіков Д.В. \\ аспірант \\ кафедра менеджменту та логістики \\ Одеська національна академія харчових технологій \\ вул. Канатна, 112, м. Одеса, Україна, 65039 \\ E-mail: Sedikov94@ukr.net
}

\title{
УКРАЇНСЬКІ РЕАЛІЇ ЩОДО СОЦІАЛЬНОЇ ВІДПОВІДАЛЬНОСТІ БІЗНЕСУ У СУЧАСНИХ УМОВАХ
}

В статті розкрито сутність глобальної та географічної моделі соціальної відповідальності. Відмічено, що глобальна модель соціальної відповідальності базується на етичній поведінці бізнесу, географрічна модель представлена трьома теоріями: корпоративного егоїзму, корпоративного альтруїзму та розумного егоїзму. До основних національних моделей соціальної відповідальності віднесено американську, європейську, японську. Доведено, що американська модель суспільної відповідальності базується на потужних активностях бізнесу при слабкому впливу центральних органів держави та громадських організацій. В європейській моделі бізнес при вирішенні соціальних проблем активно взаємодіє з державою, некомерційними організаціями та іншими громадськими інститутами. В японській моделі підприємство асоціюється з «виробничою сім'єю», де працівник несе відповідальність і користується правами, виходячи далеко за рамки трудових обов'язків. Дано авторське визначення терміну для українських реалій полягає в доповненні і набуває наступного значення «соціальна відповідальність» - це спроба вирішити соціальні проблеми, які повністю або частково спричинені діяльністю підприємств та непрофесійними і безвіподальними діями владних структур держави.

Ключові слова: соціальна відповідальність, бізнес, концепції, глобальна та географічна моделі, суспільна відповідальність.

This work is licensed under a Creative Commons Attribution 4.0 International License http://creativecommons.org/licenses/by/4.0/

Постановка проблеми та її зв'язок з важливими науковими та практичними завданнями. Перехід України від планової моделі управління народним господарством до ринкової моделі управління національною економікою спричинив кризи у більшості галузей країни. Згідно прийнятою Україною неоліберальної моделі держава не повинна управляти економікою. Дана функція належить бізнесу. Втім за роки незалежності в Україні намітилися вкрай негативні тенденції в багатьох сферах, в тому числі в економіці, соціальній, демографічній та екологічній сфеpax. 3 погляду на позакритичні тенденції в країні, відсутність фінансових ресурсів, держава ні теоретично, ні практично не в змозі опанувати кризові ситуації. Вирішення означених проблем можливе тільки в співпраці держави і бізнесу. Бізнес повинен нести повну соціальну відповідальність за кризовий стан в країні і прийняти максимально ефективні дії для виправлення становища.

Аналіз останніх публікацій по проблемі. Участь бізнесу у розв'язанні соціальних проблем населення України є предметом наукових досліджень, українських і зарубіжних вчених, представників бізнес-еліти і громадських діячів. Вагомим внеском у розвиток наукових уявлень про соціальну відповідальність бізнесу стали праці як закордонних так і вітчизняних вчених К. Аннана, П. Друкера, Ф. Котлер, А. Динкіна, А. Алексеєва, В. Воробей, Р. Гальчак, Х. Гордон Фітч, Д. Крепак, А. Кузнєцової, Н. Лі, В. Мандибури, С. Мельник, С. Перегудова, Ш. Рамазанова, Т. Смовженко, С. Черних та інших.

Формулювання цілей дослідження. Метою статті є дослідження українських реалій щодо соціальної відповідальності держави та бізнесу в сучасних умовах, визначенні причин критичного стану економіки, соціальної, демографічної і екологічної сфер та означення шляхів їх оздоровлення.

Виклад основних результатів та їх обгрунтування. У 70-х pp. XX ст. Х. Гордон Фітч визначив що «соціальна відповідальність - це спроба вирішити соціальні проблеми, які повністю або частково спричинені діяльністю підприємств» [14]. Погоджуючись 3 визначенням X. Гордон Фітчем, та 3 погляду на українські реалії $€$ необхідність в уточненні визначення даного терміну. Авторське визначення терміну для українських реалій полягає в доповненні і набуває наступного значення: соціальна відповідальність - це спроба вирішити соціальні проблеми, які повніс- 
тю або частково спричинені діяльністю підприємств та непрофесійними і безвіподальними діями владних структур держави. Дослідження показують, що вектор дії соціальної відповідальності сьогодення реалізуються глобальною та географічною моделями. Глобальна модель соціальної відповідальності базується на етичній поведінці бізнесу, добровільних ініціативах 3 покращення умов праці співробітників корпорацій, здійсненням заходів із захисту довкілля, розробки та реалізації соціальних проектів щодо розвитку громад та територій дислокації бізнесових структур. Географічна модель соціальної відповідальності бізнесу представлена трьома теоріями: корпоративного егоїзму, корпоративного альтруїзму та розумного егоїзму. Сутність теорії корпоративного егоїзму М. Фрідман сформулював так «єдиною відповідальністю бізнесу є збільшення прибутків для своїх акціонерів. 3 позиції цієї теорії бути соціально відповідальним означає платити високі податки державі, створювати робочі місця, виплачувати гідну заробітну плату найманим працівникам і виконувати закони» [15]. М Фрідман у своїй роботі відмічає «...мало що може так загрожувати самим основам нашого вільного суспільства, як згода лідерів корпорацій добрати на себе іншу соціальну відповідальність, крім тієі, яка полягає в зароблянні грошей для своїх акціонерів» [15]. Дана теорія належить до американської моделі соціальної відповідальності.

Теорія корпоративного альтруїзму передбачає, що дотримання законодавчих норм та сплата податків та зборів - це мінімум. Бізнесові структури повинні приймати активну участь у покращенні рівня життя суспільства. Соціальна відповідальністю у країнах СС це поєднання високоякісних товарів/послуг та заходів зі зниження безробіття. Теорія представлена європейською моделлю соціальної відповідальносTi.

Теорія розумного егоїзму передбачає, що соціальна відповідальність бізнесу збільшуе втрати прибутку в короткостроковому періоді за рахунок кредитування соціальних та філантропічних програм, однак у довгостроковому періоді створює відповідне соціальне оточення і як наслідок постійний прибуток. Дану теорію відносять до «змішаної моделі соціальної відповідальності» чи «корпоративної соціальної відповідальності», ідею якої належить Кофі Аннану. В Давосі, на всесвітньому економічному форумі, він запропонував ведучим компаніям світу приєднатися до Глобального договору - лейтмотивом якого $\epsilon$ співпраця бізнесу та організацій різних сфер діяльності з ООН задля всебічного впровадження в життя принципів соціальної рівноваги та захист довкілля. В нагальний час функціонує декілька видів національних моделей соціальної відповідальності, в основі формування яких покладено різновекторні критерії; суспільно-економічні уклади, напрями розвитку економіки, стилі управління, національні традиції, інші. До основних національних моделей соціальної відповідальності слід віднести американську, європейську, японську. Американська модель суспільної відповідальності базується на потужних активностях бізнесу при слабкому впливу центральних органів держави та громадських організацій. Рішення соціальних проблем здійснюються завдяки використанню законодавчо закріплених механізмів через пенсійні, освітні, медичні реформи та програми на місцевому рівні (місцевою владою та місцевим бізнесом). Діючі механізми стимулюють підприємства та зменшують вплив держави. Специфічними рисами цієї моделі виступають:

- добровільність бізнесу у вирішенні соціальних проблем, при чітко окреслених напрямах діяльності;

- напрямами діяльності бізнесу виступають соціальні проблеми рівня місцевих органів самоврядування та окремого регіону;

- вирішення конкретних соціальних проблем контролюється бізнесом через цільове використанням виділених коштів та досягненням результатів заходу;

- не пряме втручання держави здійснюється методами стимулювання соціально відповідальної діяльності компаній; На перевагу американській моделі соціальної відповідальності, європейська модель базується на значному державному регулюванні. В європейській моделі бізнес, при розв'язанні проблем соціальної сфери, активно взаємодіє 3 державою та іншими інститутами. У [5] наведено особливості Європейською моделі, а саме:

- високим рівнем інтеграції соціальної діяльності в корпоративну стратегію розвитку організації;

- держава установлює правила поведінки та контролює їх виконання;

- громадськість проявляє високу зацікавленість;

- проведенню соціальних заходів передує їх економічне обгрунтування з постійним контролем за їх ефективністю;

- враховуючи високий рівень податків, відсутність преференцій та пільг, інститут благодійництва практично відсутній.

В японській моделі підприємство асоціюється 3 «виробничою сім'єю», де працівник несе відповідальність і користується правами, виходячи далеко за рамки трудових обов'язків. Зі сторони корпорації працівник отримує різносторонню допомогу: в забезпеченні житлом, фінансовій допомозі при народженні дітей, їх навчанню, виплаті корпоративної пенсії. В Японії механізми «довічного найму», «принципу старшинства» при оплаті праці не закріплені законодавчо, але є практично соціальним імперативом, що реалізовується в більшості крупних компаній. Висновком аналізу моделей соціальної відповідальності та умов, за яких вони формувалися, виступає необхідність пошуку такої моделі, яка відповідає вітчизняній специфіці.

Приклади елементів «соціальної відповідальності» в Україні сягають часів Київського князя Володимира, Ярослава Мудрого.

Особливої поваги заслуговує сім'я цукрозаводчика Артемія Яковича Терещенко та його синів. Так у А. Я. Терещенко постійний працівник цукрового заводу отримував заробітну плату, безоплатне 
житло та харчування, сезонні працівники отримували кожний день окрім заробітної плати кілограм хліба, чотириста грам м'яса, сто грам сала та овочі. При кожному цукровому заводі була школа, лікарня, ремісне училище а також харчевня. У рідному м. Глухові на кошти мецената були побудовані жіноча та чоловіча гімназії, педагогічний інститут, будівля банку, побудовані цілі вулиці житла для бідних. В Києві на кошти Терещенко побудовані музеї, театри, церкви, гімназії, приюти для дітей, медичні заклади. Передаючи бізнес синам Артемій Терещенко заповів, щоби від прибутку сімейного бізнесу $80 \%$ направлялося на меценатство.

Завдячуючи меценатам та філантропам Л. I. Бродськиому, Г. Е. Вейнштейну, М. П. Дегтереву, С. X. Чикаленко, I. Г. Харитоненко та іншим Україна отримала лікарні, інститути, музеї, школи, дитячі притулки та інші заклади соціального, культурного напряму.

Щодо сьогодення, то в Україні не існує притаманній іiі моделі соціальної відповідальності, незважаючи на наявність законодавчої бази.

Законодавство щодо соціальної відповідальності, благодійництва (меценатсва, волонтерства). базується на відповідних положеннях Конституції України, Цивільного кодексу України, Закону України "Про благодійництво і благодійні організаціі”, Закону «Про меценатство», інших нормативноправових актів України.

В Законі України «Про благодійну діяльність та благодійні організації сформовані основні засади благодійної діяльності. Цим законом «благодійництво» визначається як добровільна особиста, майнова допомога для досягнення визначених цілей. Благодійність охоплює такі сфери діяльності як: охорона здоров'я; соціальний захист, соціальні послуги, соціальне забезпечення; освіта і наука; сприяння обороноздатності країни; захист населення у надзвичайних ситуаціях; допомога біженцям, внутрішнім переселенцям, постраждалим внаслідок катастроф, збройних конфліктів; опіка і піклування; розвиток територіальних громад: сприяння здійсненню державних програм, що спрямовані на поліпшення соціальноекономічної ситуації та ін.

Згідно Закону «Про меценатство», меценатство це добровільна безкорислива матеріальна, фінансова, організаційна, консультаційна та/або інша підтримка меценатами набувачів меценатської допомоги, спрямована на розвиток культури, мистецтва, науки, освіти охорону та популяризацію культурної спадщини

Відповідно до Закону України "Про волонтерську діяльність”, прийнятого Верховною Радою 19 квітня 2011 року, “волонтерська діяльність добровільна, безкорислива, соціально спрямована, неприбуткова діяльність, що здійснюється волонтерами та волонтерськими організаціями шляхом надання волонтерської допомоги. Волонтерська допомога - роботи та послуги, що безоплатно виконуються та надаються волонтерами та волонтерськими організаціями. Волонтерська діяльність є формою благодійництва".

Результати опитуванням менеджерів бізнесструктур щодо запровадження механізмів соціальної відповідальності підприємств: - 53,3 \% підприємств підтримують ідею запровадження політики соціальної відповідальності, - 41,1\% враховують, що підтримка даної політики для бізнес-структур не $є$ актуальним, - 5,6\% підприємств не підтримують таку практику. При цьому 29,6\% вітчизняних підприємств мають власну стратегію соціальної відповідальності, через брак коштів третина не впроваджують заходи із соціальної відповідальності, а кожна десята бізнесструктура вважає, що це повинно виконувати державі, а не бізнес.

В ряду вітчизняних компаній, які проповідують соціальну відповідальність $є$ компанія «НІБУЛОН». Генеральний директор ТОВ СП «НІБУЛОН» Олексій Вадатурський вважає, що «соціальна відповідальність для компанії - це не спонсорство і не реклама, а щира зацікавленість у наданні українській громаді широких можливостей, покращенні рівня життя кожного українця» [16]. Сталий розвиток українського суспільства це базовий аспект стратегії компанії «НІБУЛОН» 3 розвитку вітчизняного аграрного сектору. Напрямами соціально відповідального підходу до здійснення бізнесу компанією є: підтримка працівників у здобутті базової освіти; підвищення рівня медичного обслуговування; відновлення соціальної інфраструктури у сільських поселеннях; охорона та збереження навколишнього середовища; впровадження енергозберігаючих інноваційних виробничих технологій; надання рівних можливостей та створення найкращих умов праці.

В момент переходу України до ринкової моделі управління національною економікою одночасно вирішувалися дві глобальні задачі: державотворення самостійної України та демонтаж плановоцентралізованої моделі управління національною економікою та запровадження ринкової моделі. Непрофесійна приватизація та усунення держави від управління економікою на перших етапах ринкових трансформацій створили умови формування нової економічної еліти (олігархічних структур). Консолідація нової економічної еліти набагато випередила динаміку розвитку держави. Представники українського бізнесу, прагнучи зберегти власні капітали, перебрали на себе завдання стратегічного управління та регулювання, в тому числі - загальнодержавного рівня, роблячи це, зрозуміло, на базі власних корпоративних інтересів. Фактично в Україні влада і великий бізнес представлені одними особами. Таким чином причинами кризового стану в Україні, $є$ дія бізнес структур та результати неефективного управління владних структур при вирішенні соціально важливих завдань в забезпеченні життєдіяльності регіонів та держави в цілому. Економічна, демографічна, екологічні кризи та військові дії призвели до зубожіння населення. Станом на 2018 рік Україна є найбіднішою країною в Свропі з середнім доходом у. Економічна криза в Україні $є$ похідною від демографічної та військової кризи. 3 цієї причини слід дослідити 
першоджерела демографічної кризи. Демографічна криза в Україні призвела до критичного рівня народжуваності, при якому забезпечується лише половина потрібного для відтворення населення. Згідно статистичним показникам, Україна перейшла рівень зниження народжуваності, що призводить незворотне руйнування демографічного потенціалу. 3 причин низької народжуваності та високого рівня смертності Україна за роки незалежності втратила майже 10 млн. людей і сьогодні населення складає 42,3 млн., проти 52,1 млн. у 1991 р. Для відтворення кількості населення до рівня 1991 року необхідно досягти народжуваності до 2,2 - 2,3 дитини на двох батьків. На сьогодні цей показник - 1,1 дитини на одну сім'ю, що спричиняє зменшення кількості населення майже на 350 тис. осіб щороку. Працездатне населення України на 2018 рік складає 30 мільйонів жителів, при цьому офіційна робота $є$ у 16 мільйонів українців. Також в Україні проживає 6 мільйонів людей пенсійного віку [6]. Наступним фактором катастрофічного стану України є екологічна безпека держави. Лише 15,3\% населення проживає в умовах слабкого забруднення повітря, 52,8 \% помірного, 24,3\% - сильного та 7,6 \% дуже сильного [1]. Як визначає Рамазанов Ш.Ш., на виправлення катастрофічного становища на душу населення виділяється 3 дол. США щорічних природоохоронних асигнувань, що в 50 разів менше, ніж у Німеччині. Україна посідає останнє місце в Європі за смертністю від серцево-судинних хвороб, утричі випереджаючи розвинені країни. Частка працездатного населення в Україні є найменшою (смертність за період 2000 - 2015 р. зросла на $30 \%$ загалом і на $40 \%$ серед чоловіків зокрема) [10]. Кардинально змінити ситуацію можливо тільки у тісній співпраці держави та бізнесу, тобто бізнес повинен поділити з державою соціальну відповідальність за стан речей у країні. На сучасному етапі, з огляду на традиції української доброчинності, питання корпоративної соціальної відповідальності, стає вкрай актуальним нині для України.

У 2007 році Україна приєдналася до розробки міжнародного стандарту з соціальної відповідальності ISO 26000:2010 «Керівництво із соціальної відповідальності», який офіційно був опублікований в 2010 році. Так, на сьогодні діє Центр розвитку корпоративної соціальної відповідальності та спільнота «Соціально Відповідальний Бізнес. У лютому 2010 р. відбулось перше засідання Консультативної Ради з розробки Національної концепції розвитку соціальної відповідальності бізнесу в державі. В Україні налічується понад 140 підписантів-учасників Глобального Договору ООН (The Global Compact) - ініціативи, спрямованої на поширення відповідального корпоративного громадянства і на те, щоб комерційні компанії брали участь у вирішенні проблем, які постають зв'язку 3 глобалізацій ними процесами.

Щодо процесу розвитку соціальної відповідальності в Україні, то його умовно можна поділити на такі етапи:

1. Дотримання діючого законодавства - компанії виконують нормативно-правові норми, визначе- ні законодавством країни. Більшість українських компаній знаходиться саме на цьому етапі.

2. Здійснення доброчинної діяльності - компанії надають спонсорські внески на соціальні проекти. В Україні утворилась критична маса компаній, які займаються стратегічною доброчинністю та підтримують довгострокові соціальні ініціативи.

3. Використання зв'язків з громадськістю (PR) - задля підвищення власної репутації та утворення маркетингових переваг компанії здійснюють проекти, націлені на зв'язки з громадськістю, часто на основі соціальних проектів та точкових ініціатив

4. Покращення ефективності бізнес-процесів - компанії здійснюють проекти, які призводять до зростання прибутковості діяльності та вирішення соціальних та екологічних питань. Часто такі проекти пов'язані із економією ресурсів. Слід зазначити, що впродовж останніх п'яти років великий український бізнес активно впроваджував такі точкові покращення поза СВБ.

5. Стратегічний підхід до соціальної відповідальності - компанії визначають стратегію власної соціальної відповідальності, яка охоплює основні бізнес-процеси компанії (виробництво, продажі, маркетинг, стратегічне управління тощо), визначає середньо- та довгострокові цілі. СВБ використовується як інструмент корпоративного розвитку для отримання конкурентних переваг.

Соціальна відповідальність бізнесу - відповідальне відношення будь-якої бізнес-структури до:

власного продукту (забезпечення задекларованої якості, безпеки, сервісний супровід впродовж життєвого циклу);

працівників компанії (основного ресурсу компанії, який забезпечує створення доданої вартості, виплата високих доходів, надання можливості професійному розвитку, кар'єрного зростання), споживачів продукції компанії (повна інформованість, щодо продукту, відповідність взаємозв'язку «ціна - якість»;

партнерів (встановлення партнерських відносин та взаємодія як з власними підрозділами в технологічному ланцюгу);

участь у вирішенні екологічних проблем регіону, шляхом удосконалення власного виробництва направленого на ліквідацію шкідливих викидів, зливів та співпраця з партнерами. які дані принципи декларують і підтримують);

активна соціальна позиція компанії, що полягає в гармонізацій ній взаємодії та безперервному спілкуванні з суспільством, участі у розв'язанні гострих соціальних питань.

До переліку концепцій соціальної відповідальності бізнесу можна віднести:

- концепцію економічної відповідальності комерційна діяльності підприємства забезпечує прибутковості та рентабельності виробництва;

- концепцію базової бізнес-стратегії - між підприємством та суспільством існує симбіотичний зв'язок, суспільство створює умови розвиток бізнесу, який в свою чергу сприяє розвитку суспільства загалом; 
- концепцію обов'язків - до обов'язків бізнесу належать: економічні (зростання прибутків), правові (дія у межах закону), етичні (дотримуватись принципів справедливості та чесності) та філантропічні (діяльність підприємства має бути корисною для суспільства);

- добровільна концепція - поряд з короткостроковими зобов'язаннями перед суспільством бізнес має й довгострокові цілі, які базуються на загальній користі підприємницької діяльності для суспільства загалом;

- концепція проактивності - специфіка реакції підприємства на вимоги суспільства: реактивні миттєвий відгук на певні проблеми та вимоги, і проактивні - стратегічні, планові дії, які забезпечують розвиток підприємства одночасно з суспільством;

- концепція зацікавлених осіб - вплив на дію підприємства працівників, аукціонерів, постачальників, покупців, громадських організацій, держави в питаннях соціальної відповідальності.

Так склалося історично, що в Україні влада $\mathrm{i}$ великий бізнес представлені практично одними особами, які за займаними посадами в управлінні державою та управлінні бізнесом змушені нести соціальну відповідальність. Соціальна відповідальність середнього та малого бізнесу у сучасних умовах проявляється через його функції в національній економіці. Мале підприємництво утворює конкурентне середовище, швидко реагує на зміни зовнішнього середовища, придає ринковій економіці більшої гнучкості завдяки запровадженню інновацій, важливих розробок, перш за все у галузі електроніки, кібернетики, інформатики, вирішує проблему зайнятості завдяки, створюючи нові робочі місця та вбирати надлишкову робочу силу під час коливань і структурних зрушень економіки. Головне призначення малого бізнесу полягає в послабленні соціальної напруги і демократизації ринкових відносин, бо якраз воно є підвалиною формування середнього класу. Отже слід наголосити, що роль та функції малого та середнього бізнесу зво- диться до того, що він є головним дієвим фактором економічного зростання суспільства, який посилається на ринкові методи ведення бізнесу. Його місією $є$ підтримка соціальної, політичної, економічної стабільності суспільства, тобто воно надає обшир вільному вибору напрямів діяльності на користь суспільства та забезпечення власного добробуту.

Висновки та перспективи подальших досліджень. Найбільш больовими точками сьогодення України є корумпованість владних структур; військові дії на сході країни, які відволікають значні фінансові ресурси; різкий спад розвитку економіки, який спричинив низький рівень оплати праці та низьку платоспроможність населення, демографічну кризу, еміграцією населення; екологічну безпеку та інші. Негативні явища в галузях народного господарства, соціальному середовищі, вимагають негайних дій задля виправлення означеного становища яке можливе в тісному співробітництві держави і бізнесу. На сучасному етапі розвитку соціальна відповідальність в Україні знаходиться на етапі становлення. На наш погляд, для активізації соціальної відповідальності необхідно залучати іноземні компанії, які привносять в українське середовище новітні світові практики, методи, стандарти, та активізувати діяльність великих українських підприємств.

Благодійность (волонтерство) населення України в підтримці розбудови української армії, підтримці біженців, надання гуманітарної допомоги в районах проведення АТО - $\epsilon$ історичним потенціалом нації спрямованому на поліпшення соціальноекономічної ситуації.

Соціальна відповідальність бізнесу та держави є дії, щодо ліквідації наслідків негативного впливу діяльності бізнесу на довкілля, соціальний стан в державі. Вирішенням даного питання може бути тільки через прийняття законів, які регламентують нульовий негативний вплив бізнесу на довкілля, соціальний стан населення країни.

\section{Література}

1. Бондаренко Л. Г. Навколишне середовище i здоров'я населення. URL: // https://vseosvita.ua/library/navkolisne-seredovise-i-zdorova-naselenna-ekologicna-bezpeka-gigienicnij-poglad-cerezroki-16930.html (дата звернення 26.10. 2018).

2. Джорж Р. Т. Деловая этика / Джорж Р. Т.; пер. с англ. Р. И. Стопера. СПб., 2001. 405 с. (англ. яз.).

3. Індикатори стану екологічної безпеки держави. Аналітична записка. URL: // http://www.niss.gov.ua/articles/993 (дата звернення 27.10. 2018).

4. Котлер Ф., Лі Н. Корпоративна соціальна відповідальність. Як зробити якомога більше добра для вашої компанії та суспільства / Котлер Ф., Н. Лі; пер. 3 англ. С. Яринич. К., 2005. 302 с. (англ. яз.).

5. Корпоративна соціальна відповідальність: підручник / О. Гирик та ін; Київ: УБС НБУ, 2009. 258 с.

6. Крепак Д. Працювати на суспільство: що таке корпоративна соціальна відповідальність бізнесу. URL:http://forbes.net.ua/ua/opinions/1413277-pracyuvati-na-suspilstvo-shcho-take-korporativna-socialnavidpovidalnist-biznesu (дата звернення 26.10. 2018).

7. Лазоренко О. Корпоративна соціальна відповідальність в Україні: експертна думка // зб. статей та рекомендацій Нац. ун-т харч. технологій. Київ, 2007. № 19. С. 152

8. Населення України на 2018 рік кількість на сьогодні. URL: http://2018.pp.ua/novini-2018/2834naselennya-ukrayini-na-2018-rk-klkst-na-sogodn.html (дата звернення 26.10. 2018).

9 Петроє О.М. Соціальний діалог як інструмент формування корпоративної соціальної політики: монографія. Київ: Центр учбової літератури, 2008. 152 с. 
10. Рамазанов Ш.Ш. Демографічна ситуація в Україні: проблеми та шляхи її вирішення // Інтелігенція і влада. Серія «Соціологія». 2007. № 12. С. 104-113.

11. Рощина Н. В., Черненко Н. О., Солодовник Л. М. Щодо питання підтримки соціальної відповідальності держави.// Державне управління: удосконалення та розвиток. 2006. № 3.

12. Савенко I. I. Реконструктивний тип адаптування реального сектору економіки та галузевої науки України до умов постіндустріального суспільства: / за ред. Савенка I. І., Станкевича Г. М., Седікової І. О. Одеса: КП «Одеська міська друкарня», 2017. 644 с.

13. Сучасний стан галузей національної економіки України: проблеми та шляхи вирішення / за ред. I. I. Савенко, І. О. Седікової. Харків: ТОВ «Пром-Арт», 2018. 433с.

14. Гордон Х. Фитч. Корпоративная ответственность перед обществом. Корпоративный социальный отчет. Рекомендации Ассоциации менеджеров. URL: // http: //www.amr.ru (дата звернення 26.10. 2018).

15. Фридман М. Капитализм и свобода; пер. с англ. В. П. Костанди. М., 2006. 240 с. 2018).

16. Офіційний сайт компанії НІБУЛОН. [Веб-сайт]. URL: http://nibulon.com (дата звернення 26.10.

Стаття надійшла 30.10.2018

Стаття прийнята до друку 13.11.2018

Доступно в мережі Internet 29.12.2018

\author{
Савенко И.И. \\ доктор экономических наук, профессор \\ E-mail: kaf-ml@gmail.com \\ Седиков Д.В. \\ аспирант \\ кафедра менеджмента и логистики \\ Одесская национальная академия пищевых технологий \\ ул. Канатная, 112, г. Одесса, Украина, 65039 \\ E-mail: Sedikov94@ukr.net
}

\title{
УКРАИНСКИЕ РЕАЛИИ СОЦИАЛЬНОЙ ОТВЕТСТВЕННОСТИ БИЗНЕСА В СОВРЕМЕННЫХ УСЛОВИЯХ
}

В статье исследованы украинские реалии социальной ответственности бизнеса в современных условиях. Объектом исследования является социальная ответственность бизнеса в национальных экономиках. Предметом исследования являются механизмы социальной ответственности бизнеса в современных условиях функционирования национальной экономики Украины.

Дано авторское определение термина «социальная ответственность». Социальная ответственность - это попытка решения социальных проблем, которые полностью или частично вызваны деятельностью предприятий и непрофессиональными, безответственными действиями частных структур. Исследования показали, что вектор действия социальной ответственности в настоящее время реализуется глобальной и географической моделям. Глобальная модель базируется на этическом поведении бизнеса, добровольных инициативах по улучшению условий труда сотрудников корпораций, осуществлением мероприятий по защите окружающей среды, разработки и реализации социальных проектов по развитию общества и территорий. Географическая модель представлена тремя теориями: корпоративного эгоизма, корпоративного альтруизма и разумного эгоизма. Установлено, что в настоящее время функционирует несколько видов национальных моделей социальной ответственности, в основе формирования которых положены разновекторные критерии; общественноэкономические уклады, направления развития экономики, стили управления, национальные традиции и т. д.. К основным национальным моделя социальной ответственности отнесены американскую, европейскую, японскую.

Рассмотрена история меценатства в Украине в историческом разрезе. Приведены результаты опроса менеджеров бизнес-структур по внедрению механизмов социальной ответственности предприятий. Доказано, что социальная ответственность бизнеса - ответственное отношение любой бизнес-структуры собственной продукции, работников компании, партнеров, участие в решении экологических проблем региона, активная социальная позиция компании. В перечень концепций социальной ответственности бизнеса отнесены: концепцию экономической ответственности; концепцию базовой бизнес-стратегии; концепцию обязанностей; добровольное концепция; концепция проактивности; концепция заинтересованных лиц. Отмечено, что роль и функции малого и среднего бизнеса сводится к тому, что он является главным действующим фрактором экономического роста общества, опирающийся на рыночные методы ведения бизнеса. Его миссией является поддержка социальной, политиче- 
ской, экономической стабильности общества, они предоставляют свободный выбор видов деятельности в интересах общества и обеспечения собственного благополучия.

Ключевые слова: социальная ответственность, бизнес, концепции, глобальная и географическая модели, общественная ответственность.

\author{
Savenko I. \\ Doctor of Economics, Professor \\ E-mail: kaf-ml@gmail.com \\ Sedikov D. \\ Postgraduate \\ Department of Management and Logistics \\ Odessa National Academy of Food Technologies \\ Kanatna str., 112, Odesa, Ukraine, 65039 \\ E-mail: Sedikov94@ukr.net
}

\title{
UKRAINIAN REALITIES ON SOCIAL RESPONSIBILITY OF BUSINESS IN THE MODERN CONDITIONS
}

The article deals with the study of Ukrainian realities regarding the social responsibility of business in modern conditions. The object of research is the social responsibility of business in national economies. The subject of the study is the mechanisms of social responsibility of business in the current conditions of functioning of the national economy of Ukraine.

The author's definition of the term "social responsibility" has been given. Social responsibility is an attempt to solve social problems that are caused, in whole or partly, by enterprises activities and unprofessional and impassable actions of private structures. Studies have shown that the vector of social responsibility today is realized by global and geographic models. The global model is based on the ethical behavior of businesses, voluntary initiatives to improve the working conditions of corporate employees, the implementation of environmental protection measures, the development and implementation of social projects on community development and the placement of business structures. The geographic model is represented by three theories: corporate egoism, corporate altruism, and rational selfishness. It has been established that at the moment, several types of national models of social responsibility function, the basis of which is the multivector criteria; socio-economic patterns, directions of economic development, management styles, national traditions, etc. The main national models of social responsibility are American, European, Japanese ones.

The history of patronage in Ukraine has been considered in historical terms. The results of the survey of managers of business structures concerning introduction of mechanisms of social responsibility of enterprises have been presented. It has been proved that social responsibility of business is the responsible relation of any business structure to: own products, company employees, partners, participation in solving environmental problems of the region, active social position of the company. The list of concepts of corporate social responsibility includes: the concept of economic responsibility; the concept of a basic business strategy; the concept of responsibilities; voluntary concept; concept of proactivity; concept of stakeholders. It is emphasized that the role and functions of small and medium-sized business is reduced to the fact that it is the main effective factor of the economic growth of the society, which refers to market-based business methods. His mission is to support the social, political, and economic stability of the society, that is, it provides an enormous scope for the free choice of activities for the benefit of the society and for ensuring their own wellbeing. sibility.

Key words: social responsibility, business, concepts, global and geographic models, social respon-

\section{References}

1. Bondarenko, L. H. (2018). Navkolišnê seredoviŝe ì zdorov'â naselennâ. Retrieved October 26, 2018, from https://vseosvita.ua/library/navkolisne-seredovise-i-zdorova-naselenna-ekologicna-bezpeka-gigienicnij-poglad-cerezroki-16930.html

2. Dzhorzh, L. T. (2001). Delovaâ ètika (R. I. Stoper, Trans.). SPb.

3. İndikatori stanu ekologičnoï bezpeki deržavi. Analitična zapiska. Retrieved October 27, 2018, from http://www.niss.gov.ua/articles/993

4. Kotler, F., \& Li, N. (2005). Korporativna social'na vidpovidal'nist'. Âk zrobiti âkomoga bil'še dobra dlâ vašoï kompaniï ta suspil'stva (S. Yarynych, Trans.). Kyiv. 
5. Hyryk, O. (2009). Korporativna social'na vidpovidal'nìst'. Kyiv: UBS NBU.

6. Krepak, D. (2016). Pracûvati na suspil'stvo: ŝo take korporativna socìal'na vìdpovìdal'nìst' bìznesu. Retrieved October 26, 2018, from http://forbes.net.ua/ua/opinions/1413277-pracyuvati-na-suspilstvo-shcho-takekorporativna-socialna-vidpovidalnist-biznesu

7. Lazorenko, O. (2007). Korporativna socìal'na vìdpovìdal'nìst' v Ukraïnì: Ekspertna dumka. Zb. Statej Ta Rekomendacìj Nac. Un-t Harč. Tehnologìj, (19), 52.

8. Naselennâ Ukraïni na 2018 rìk kìl'kìst' na s'ogodnì. (2018). Retrieved October 26, 2018, from http://2018.pp.ua/novini-2018/2834-naselennya-ukrayini-na-2018-rk-klkst-na-sogodn.html

9. Petroie, O. M. (2008). Social'nij dialog âk instrument formuvannâ korporativnoï socìal'nö̈ politiki. Kyiv: Centr učbovoï lìteraturi.

10. Ramazanov, Sh. Sh. (2007). Demografična situaciâ v Ukraïnì: Problemi ta šlâhi iï virišennâ. İnteligenciâ $i$ Vlada. Serî̀ «Sociologî̀», (12), 104-113.

11. Roshchyna, N. V., Chernenko, N. O., \& Solodovnyk, L. M. (2006). Sodo pitannâ pìdtrimki socìal'noï vìdpovìdal'nostì deržavìi. Deržavne Upravlìnnâ: Udoskonalennâ Ta Rozvitok, (3).

12. Savenko, I. I. (2017). Rekonstruktivnij tip adaptuvannâ real'nogo sektoru ekonomiki ta galuzevoï nauki Ukraïni do umov postìndustrial'nogo suspil'stva (I. I. Savenko, H. M. Stankevych, \& I. O. Sedikova, Eds.). Odesa: KP «Odeska miska drukarnia».

13. Savenko, I. I., \& Sedikova, I. O. (Eds.). (2018). Sučasnij stan galuzej nacional'noï ekonomiki Ukraïni: Problemi ta šlâhi virišennâ. Kharkiv: TOV «Prom-Art».

14. Fitch, G. H. Korporativnaâ otvetstvennost' pered obŝestvom. Korporativnyj social'nyj otčet. Rekomendacii Associacii menedžerov. Retrieved October 26, 2018, from http://www.amr.ru

15. Fridman, M. (2006). Kapitalizm i svoboda (V. P. Kostandi, Trans.). Moskva.

16. Ofìcijnij sajt kompaniï NİBULON. Retrieved October 26, 2018, from http://nibulon.com

Received 30 October 2018 Approved 13 November 2018 Available in Internet 29.12.2018

Цитування згідно ДСТУ 8302:2015

Савенко І.І., Седіков Д.В. Українські реалії щодо соціальної відповідальності бізнесу у сучасних умовах // Економіка харчової промисловості. 2018. Т.10, вип. 4. С. 102-108. doi: 10.15673/fie.v10i4.1138

Cite as APA style citation

Savenko I., \& Sedikov D. (2018). Ukrainian realities on social responsibility of business In the modern conditions. Food Industry Economics, 10(4), 102-108; doi: 10.15673/fie.v10i4.1138 